\title{
Portfolio management and retirement: what is the best arrangement for a family?
}

\author{
Thomas Post • Helmut Gründl • Hato Schmeiser
}

Published online: 21 July 2006

(C) Swiss Society for Financial Market Research 2006

\begin{abstract}
In comparing an immediate life annuity with a payout-equivalent investment fund payout plan (self-annuitization), research to date has focused mainly on shortfall probabilities of self-annuitization. As an exception, Schmeiser and Post (2005) propose a family strategy where the chances of self-annuitization (i.e., bequests) are taken into consideration as well. In such a family strategy, potential heirs must bear shortfall risks, but in return have a chance of receiving a bequest. This paper analyzes under which conditions heirs will be willing to agree to a family strategy. The idea of a family strategy is integrated into a realistically calibrated intertemporal expected utility framework, taking into account risks arising from stochastic life span, asset returns, and nontradable labor income. A family strategy is shown to be accepted for many parameter combinations, especially in families with low marginal tax rates, if the heirs are wealthy, or in a case where the retiree has an average population life expectancy. We also work out how family self-annuitization decisions interact with asset allocation, saving decisions, and labor income risk. Under realistic conditions our results support two explanations for the empirically observable low demand for annuities (the so-called annuity puzzle), namely intra-family risk sharing and high cost of market-annuitization.
\end{abstract}

Keywords Self-annuitization · Life-cycle asset allocation - Savings behavior . Retirement decisions

\footnotetext{
T. Post · H. Gründl

Dr. Wolfgang Schieren Chair for Insurance and Risk Management,

Humboldt-Universität zu Berlin, Berlin, Germany

H. Schmeiser $(\bowtie)$

Institute of Insurance Economics, University of St. Gallen, St. Gallen, Switzerland

e-mail: hato.schmeiser@unisg.ch
} 
JEL Classification Number $\quad \mathrm{D} 13 \cdot \mathrm{D} 14 \cdot \mathrm{D} 91 \cdot \mathrm{G} 11 \cdot \mathrm{G} 22 \cdot \mathrm{G} 23$

\section{Introduction}

According to Yaari's (1965) seminal paper, expected utility maximizers without bequest motives should annuitize their entire wealth, given a fair life annuity market. This result was recently confirmed by Davidoff et al. (2005) under more general assumptions about utility functions. However, annuity markets are, in general, far from being perfect since only unfairly priced annuities are available due to adverse selection ${ }^{1}$ and transaction costs (Mitchell et al. 1999; von Gaudecker and Weber 2004). In this context, several authors propose selfannuitization strategies in order to beat the market-annuitization benchmark (e.g., Milevsky et al. 1997; Milevsky and Robinson 2000; Albrecht and Maurer 2002; Milevsky and Young 2003, 2005; Blake et al. 2003; Young 2004; Milevsky 2005; Schmeiser and Post 2005). The self-annuitization strategies are individual payout plans - typically investment-fund based-that attempt to replicate the payout stream of a life annuity. The literature mainly focuses on the shortfall risk of self-annuitization strategies and shows that - dependent on the riskiness of the asset allocation and the annuity buyer's age - it is possible to minimize, but never fully eliminate, shortfall risk in the case of fixed-payout annuities. This means that there is always a risk of outliving one's money. ${ }^{2}$

Schmeiser and Post (2005) argue that knowing only the probability of outliving one's money does not provide enough information for the self- versus market-annuitization decision because self-annuitization strategies bring about risks and chances. Self-annuitization strategies - in contrast with traditional life annuities - create the chance to bequeath wealth if a retiree does not outlive his money. However, a retiree in pursuit of a self-annuitization strategy would have to bear the shortfall risks, whereas the chances (i.e., bequests) are on the heirs' side (if the retiree has no utility of bequest). Schmeiser and Post (2005) propose a family strategy where heirs bear both chances and risks. The starting point of this strategy is an insurance company's offer of an immediately beginning life annuity. Instead of investing money in this annuity, the retiree is offered a second alternative. He invests the money in an investment fund and generates the same payout stream that would have been provided by the insurance company. In this family strategy, the future heirs have to bear the risk that the fund will be exhausted during the retiree's lifetime. In contrast to the market insurance alternative, however, there is still a chance to inherit a share of the money invested. The family might also save costs of adverse selection - assuming symmetric information within the family - and transaction costs - assuming

\footnotetext{
1 The facts that typical annuitants have an above average life expectancy and that annuities are priced according to their mortality makes annuities "unfair" for the average population.

2 In the case of a variable-payout annuity Milevsky and Young (2005) show that under certain assumptions it is possible to find a self-annuitization strategy that dominates the payout of the annuity.
} 
a certain level of mutual trust and honesty within the family (Kotlikoff and Spivak 1981).

Utilizing a simulation-based technique Schmeiser and Post (2005) calculate the probability distribution of the cash flows of the family strategy at a certain point in time. Even though the chance and risk profile of the family strategy looks promising, there is still no clear indication as to whether heirs would be willing to act as insurance providers, since no utility-based valuation of the cash-flow distribution has yet been done. Hence, it is still unknown whether the chances of such a family strategy are high enough to compensate for the risks taken.

The goal of this paper is to analyze under which conditions-especially with respect to preferences, financial wealth position, biometric risks, and marginal taxation rates - heirs will be willing to agree to a family strategy.

In our model, the idea of a family strategy is integrated into a realistically calibrated discrete time-intertemporal consumption/saving-expected utility framework. We calibrate our model to account for risks arising from stochastic life span, asset returns, and nontradable labor income. A family strategy is shown to be accepted for many parameter combinations, especially in families with low marginal tax rates, if the heirs are very wealthy, or in a case where the retiree has an average population life expectancy. Outside the family or annuitization context similar frameworks were recently applied by Gomes and Michaelides (2003, 2005), Dammon et al. (2004), and Cocco et al. (2005), as well as Rodepeter and Winter (2005).

The paper contributes to the optimal annuitization literature that considers family relations in the retirement context. Kotlikoff and Spivak (1981) analyzed annuitization decisions in larger families. Brown and Poterba (2000), and Vidal and Lejárraga (2006) focused on married couples. The main source of uncertainty in these expected utility models stems from the stochastic life span of the family members. Our model shows that also under more realistic conditions, i.e., in a model with asset return and labor income uncertainty, family self -annuitization proves to be optimal in many situations. We also work out how family self-annuitization decisions interact with the asset allocation and saving decisions and labor income risk. Our results support both the ideas that intrafamily risk sharing (Kotlikoff and Spivak 1981) and high cost of market-annuitization (Mitchell et al. 1999) explain the annuity puzzle, i.e. the empirically found low annuity demand. ${ }^{3}$

The paper is organized as follows. We start with a detailed description of our family strategy in section 2 . Thereafter, in section 3 , the formal expected utility model is established and calibrated with German empirical data. Then, in section 4, numerical results are presented using different input parameters. We finish with section 5, by discussing general requirements for the strategy and some limitations of the concept when put into practice.

\footnotetext{
3 Another explanation for low annuity demand is the crowding-out effect of government pensions (Mitchell et al. 1999), which means that government pensions function as a substitute for private pensions.
} 


\section{The family strategy}

The family strategy proposed in this paper is similar to the one described in Schmeiser and Post (2005) but includes some adjustments required for its integration into an intertemporal expected utility model. The starting point is a retiree who is concerned about his future financial situation, given uncertainty about how long he will live. He is endowed with a certain amount of wealth that he intends to utilize for his old age provision. For this purpose, he considers two alternatives. The first alternative is simple: he places his money with an insurance company and in return receives an immediate life annuity. The second alternative - the focus of this paper-is the family strategy. The retiree hands his money over to his heir, who promises to pay a life annuity-equivalent payment stream. To guarantee these payments, the heir is required to deposit a collateral of sufficient size, which means this strategy will work only in cases where the heir possesses at least a certain amount of wealth. In principle, the retiree is indifferent between the two alternatives described. Furthermore, one has to bear in mind that - as in Kotlikoff and Spivak (1981) - a certain level of mutual trust and honesty within the family is required. Otherwise, contractual, monitoring, adverse selection or other additional costs could practically always exceed the cost of market annuitization.

The heir's aim is to maximize the expected utility of his lifetime consumption. If he refuses to serve as an annuity provider, he cannot expect any bequest. When providing the life annuity, the chances - of course, measured only in financial terms-lie in receiving the bequest, whereas financial risks arise from the fact that the retiree may outlive the money reserved for the annuity, and therefore the heir's own capital will be reduced. This could happen if the retiree lives an unexpectedly long time and/or there is a poor development in the capital market.

The heir's optimization problem takes into account the risks from asset returns, labor income, his own life span, and - via the expectation about the payment time of the annuity-equivalent-payment stream - the retiree's life span. Besides deciding whether to provide a life annuity, the heir's decision variables are the asset allocation of his portfolio and his consumptions/savings in each future year of his life.

\section{The model framework}

\subsection{The heir's decision problem}

In this section, the integration of the heir's decision problem into a discrete time-intertemporal consumption/saving-expected utility framework is described. In the following, the time $t$ is measured in years; all monetary values are stated in nominal and after-tax terms. The heir maximizes the utility of consumption $C$ over his remaining stochastic lifetime using an intertemporalseparable utility function $U(C)$ with the form: 


$$
U(C)=\sum_{t=0}^{T-x} \delta^{t} U_{t}\left(C_{t}\right)
$$

$T$ denotes his maximum lifespan, $x$ his current age, and $\delta$ the subjective discount factor. Assuming the heir to have no bequest motive, the one-period utility function $U_{t}\left(C_{t}\right)$, which displays constant relative risk aversion of $\gamma$, is given by:

$$
U_{t}\left(C_{t}\right)= \begin{cases}\log \left(\frac{C_{t}}{(1+\pi)^{t}}\right), & \text { with } \gamma=1 \\ \frac{\left(\frac{C_{t}}{(1+\pi)^{t}}\right)^{1-\gamma}-1}{1-\gamma}, & \text { otherwise, }\end{cases}
$$

as long as the heir lives and 0 otherwise. $C_{t}$ stands for nominal consumption at time $t$ and is adjusted for an inflation rate $\pi$.

At each point in time $t$ the heir must decide how much to consume (which implicitly determines his savings) and how to invest the remaining savings (via the chosen asset allocation). Let the heir have financial wealth $W_{0}$, henceforth called "cash on hand" (Deaton 1991). If the heir decides to participate in the family strategy, his cash on hand is increased by the insurance premium $P$, transferred from the retiree. In return for this amount, he is obliged to pay an annuity $A$ each year (paid out at the end of each year) to the retiree as long as the retiree lives. Savings $S_{t}$ are allocated to both a risk-free investment and a risky investment. The proportion invested riskily each period, $\alpha_{t}$, earns the risky return $R_{t}$ whereas the rest $\left(1-\alpha_{t}\right)$ is compounded at the risk-free return $R_{f}$. We assume that the heir cannot borrow money or short-sell stocks. Stochastic (net) labor income $L_{t}$ is received by the heir from age $x$ to age 64 at the end of each year $t$. Furthermore, in order to guarantee that the retiree will be at least as well off under the family strategy as he would have been under the insurer's annuity plan, the risk-free proportion $\left(1-\alpha_{t}\right)$ of $S_{t}$ is required to be at least as large as a collateral, $\mathrm{col}_{t}$, which will be specified below.

The heir must decide at $t=0$ whether he will take part in the family strategy. To make an optimal decision, the heir maximizes expected lifetime utility, first without and then with the family strategy. He chooses the alternative that provides the highest expected utility. Hence, the maximization problem in the case where the heir decides to provide the annuity is given by:

$$
\max _{\alpha_{t}, C_{t}} \mathrm{E}_{0}(U(C)),
$$

subject to consumption constraints:

$$
\begin{aligned}
C_{0}= & W_{0}+P-S_{0} \\
C_{t}= & \underbrace{S_{t-1}\left(1-\alpha_{t-1}\right) R_{f}+S_{t-1} \alpha_{t-1} R_{t-1}-A_{t-1}+L_{t-1}}_{W_{t}}-S_{t} \\
& \forall t \in\{1,2, \ldots, T-x\},
\end{aligned}
$$


subject to borrowing/collateral size constraints:

$$
\begin{aligned}
& \operatorname{col}_{0} \leq S_{0} \leq W_{0}+P \\
& \operatorname{col}_{t} \leq S_{t} \leq W_{t} \quad \forall t \in\{1,2, \ldots, T-x\}
\end{aligned}
$$

subject to collateral investment constraints:

$$
\operatorname{col}_{t} \leq S_{t}\left(1-\alpha_{t}\right) \quad \forall t \in\{0,1, \ldots, T-x\}
$$

and subject to no-short-sale constraints:

$$
0 \leq \alpha_{t} \leq 1
$$

$W_{t}$ stands for cash on hand at time $t . A_{t}$ equals the annuity payout $A$ as long the retiree lives and 0 otherwise. The maximization problem without the family strategy is obtained by setting $P, A_{t}$ and $\operatorname{col}_{t}$ to 0 .

\subsection{Calibration and solving technique}

In this subsection, the base parameter configuration of the model is given. Later, we vary the subjective discount factor, the relative risk aversion parameter, the number of heirs, the marginal tax rate, and the mortality of the retiree. We introduce these alternative parameter values in the results section of the paper.

The financial terms of the family strategy are determined by the individual characteristics of the retiree. We assume the retiree to be age 65 , which is the statutory retirement age in Germany at present. His wealth, which shall be annuitized completely, is set to $300,000 €(=P)$. At market conditions as of the end of 2004, this yields a nominal constant annual annuity payment $A$ of $20,514 €,^{4}$ given a marginal tax rate of $0 \%$. The retiree's survival process is modeled using a cohort life-table based on data from the Federal Statistical Office Germany, which reflects expected average population mortality as of 2001.

The heir's age $x$ is set at 45 and his survival process depends on the same life-table as the retiree's. ${ }^{6}$ The maximum lifespan $T$ according to this table is 121. The heir's preferences are defined by setting $\delta=0.97$ and $\gamma=2$ (see, e.g., Laibson et al. 1998). His marginal tax rate is, for the present, also set to $0 \%$.

For the inflation rate $\pi$, the sample mean of the time series of the German consumer price index (CPI) from 1950 to 2003 (Federal Statistical Office Germany 2004) is used, resulting in $\pi=0.0263$. Stock returns $R_{t}$ are assumed to be i.i.d. and log-normal (e.g., Hull 2005). Distribution parameters are estimated

\footnotetext{
4 As in Schmeiser and Post (2005), this value is an offer of the Standard Life Insurance Company, sold in Germany.

5 The assumptions on the development of future mortality are described as "Szenario L3" in Federal Statistical Office Germany (2003).

6 Nevertheless, given some fixed age for retiree and heir (e.g., 65), the heir has a higher life expectancy than the retiree, since the life-table used is differentiated by the year of birth of a person.
} 
from a time series of the German stock index, DAX, based on annual data from 1950 to $2003 .^{7}$ Taking transaction costs of a DAX index investment fund of $0.7 \%$ p.a. of investment fund volume (paid upfront) into account ${ }^{8}$ the estimation delivers a mean $\mathrm{E}\left(R_{t}\right)$ of 1.1502 p.a. and a standard deviation $\operatorname{Std}\left(R_{t}\right)$ of 0.3157 p.a. for the log-normally distributed returns. For the risk-free return $R_{f}$ we use the sample mean of the annualized return time series of the German money market from 1950 to 2003, which leads to the value of 1.0481 p.a., ${ }^{9}$ after deducting transaction costs of a money market fund of $0.18 \%$ p.a. ${ }^{10}$

The collateral $\mathrm{col}_{t}$ is set to equal the risk-free discounted sum of future annuity payments $A$, assuming the retiree reaches the maximum life span of 121. ${ }^{11}$ Hence, $\operatorname{col}_{0}=395,777 €$. Since this amount of cash on hand has to be invested risk-free (collateral investment constraint (6)), the collateral is large enough to guarantee that-independent of the retiree's/heir's actual life span, asset returns, and labor income - the annuity payment obligations can always be met. Bearing in mind the transfer of the insurance premium $P$ of $300,000 €$ to the heir, it becomes clear that the heir needs at least 95,777€ cash on hand in order to participate in the family strategy.

Annual labor income payments $L_{t}$ are modeled to be independently distributed and are also independent from $R_{t}$. The heir receives labor income from age 45 to 64 . $\mathrm{E}\left(L_{t}\right)$ is calibrated to match an empirically observed, hump-shaped lifecycle-income profile. The heir's initial labor income is set to $30,000 €$. This value is used as the starting point of the life-cycle-income profile. Expected growthrates of labor income are based on Fitzenberger and Wunderlich (2002), and Behr et al. (2003).

Stochastic shocks to labor income enter the model from two sources. First, with probability of $1 \%$ the heir may become unemployed and receive public welfare for the current year (Lauer 2003, p. 28 and 35; Wilke 2005, p. 213 and 234). ${ }^{12}$ In this event, he is entitled to welfare benefits of $L_{t}^{u}=8,000 € \cdot(1+\pi)^{t}$ (Federal Statistical Office Germany 2002, p. 208). With probability of $99 \%$ the heir is employed. In this case-to account for labor income risks other than unemployment-his labor income $L_{t}^{e}$ is log-normally distributed. The mean of the log-normal distribution $\mathrm{E}\left(L_{t}^{e}\right)$ is set to $1 / 0.99 \cdot\left[\mathrm{E}\left(L_{t}\right)-0.01 \cdot 8,000 € \cdot(1+\right.$

\footnotetext{
7 We are greatly indebted to Professor R. Stehle, Ph.D., Chair of Banking and Stock Exchanges, Humboldt-Universität zu Berlin (Germany), for providing us with the time series of the DAX.

8 After consulting various online brokers, we found that this annual management fee is the competitive price (as of 2004).

9 See the IMF International Financial Statistics Online database, http:WWW.//ifs.apdi.net/imf.

10 See footnote 8 .

11 Formally, this means that $\mathrm{col}_{t}=A \sum_{j=1}^{T-65-t} R_{f}^{-j}$.

12 In reality, unemployment/welfare risk is above $1 \%$ p.a., the average duration of unemployment, however, is shorter than 1 year (e.g., Lauer 2003; Wilke 2005). In general, a more realistic unemployment model would have to take into account the stochastic occurrence and duration of unemployment. Therefore, in the discrete time model used here, where time progresses in steps of years, the probability to become unemployed at all is below the real-world probability, but the duration lies above the average duration of unemployment.
} 
Table 1 Base Parameter Configuration

\begin{tabular}{lll}
\hline Parameter & & Value \\
\hline Age of the retiree & & 65 \\
Insurance premium & $P$ & $300,000 €$ \\
Collateral at $t=0$ & $\operatorname{col}_{0}$ & $395,777 €$ \\
Annual annuity payment & $A$ & $20,514 €$ \\
Age of the heir & $x$ & 45 \\
Maximum lifespan & $T$ & 121 \\
Mortality & & Population average \\
Relative risk aversion & $\gamma$ & 2 \\
Subjective discount factor & $\delta$ & 0.97 \\
Marginal tax rate & & $0 \%$ \\
Inflation & $\pi$ & 0.0263 \\
Log-normal stock return & $R_{t}$ & \\
$\quad$ Expected return & $\mathrm{E}\left(R_{t}\right)$ & 1.1502 \\
$\quad$ Standard deviation of return & $\mathrm{Std}\left(R_{t}\right)$ & 0.3157 \\
Risk-free return & $R_{f}$ & 1.0481 \\
Log-normal labor income & $L_{t}$ & \\
$\quad$ Initial value of the heir's income profile & & $30,000 €$ \\
Expected income & $\mathrm{E}\left(L_{t}\right)$ & Life-cycle-income profile \\
$\quad$ Unemployment probability & & $1 \%$ \\
$\quad$ Unemployment/welfare benefits & $L_{t}^{u}$ & $8,000 € \cdot(1+\pi)^{t}$ \\
Standard deviation when not unemployed & $\operatorname{Std}\left(L_{t}^{e}\right)$ & $20 \%$ \\
\hline
\end{tabular}

$\left.\pi)^{t}\right]^{13}$. The standard deviation $\operatorname{Std}\left(L_{t}^{e}\right)$ is set to $20 \%$ (Rodepeter and Winter (2005)).

Table 1 summarizes the base parameter configuration used.

The optimization problem (3)-(7) is solved backward via stochastic dynamic programming. The Bellman equation for this problem depends on three state variables: time $t$, cash on hand $W_{t}$, and the life status of the retiree ( $a=$ alive and $d=$ dead). Let $p_{t}^{h}\left(p_{t}^{r}\right)$ denote the probability of the heir (retiree) at time $t$ to survive to $t+1$, the Bellman equation (with $V$ denoting the value function) is given by, $t=0,1, \ldots, T-x-1$,

$$
V_{t}^{d}\left(W_{t}\right)=\max _{\alpha_{t}, C_{t}}\left\{U_{t}\left(C_{t}\right)+p_{t}^{h} \delta \mathrm{E}_{t}\left(V_{t+1}^{d}\left(W_{t+1}\right)\right)\right\}
$$

subject to constraints (4)-(7), if the retiree is dead, and

$$
V_{t}^{a}\left(W_{t}\right)=\max _{\alpha_{t}, C_{t}}\left\{U_{t}\left(C_{t}\right)+p_{t}^{h} \delta\left[p_{t}^{r} \mathrm{E}_{t}\left(V_{t+1}^{a}\left(W_{t+1}\right)\right)+\left(1-p_{t}^{r}\right) \mathrm{E}_{t}\left(V_{t+1}^{d}\left(W_{t+1}\right)\right)\right]\right\}
$$

\footnotetext{
13 This adjustment guarantees that $\mathrm{E}\left(L_{t}\right)$ lies on the life-cycle-income profile. The $\mathrm{E}\left(L_{t}\right)$ can be calculated if unemployment risk is taken into account, i.e., $0.01 \cdot L_{t}^{u}+0.99 \cdot \mathrm{E}\left(L_{t}^{e}\right)=0.01 \cdot 8,000 €$. $(1+\pi)^{t}+0.99 \cdot 1 / 0.99 \cdot\left[\mathrm{E}\left(L_{t}\right)-0.01 \cdot 8,000 € \cdot(1+\pi)^{t}\right]=\mathrm{E}\left(L_{t}\right)$. 
subject to constraints (4)-(7), if the retiree is alive. In the last period, the remaining wealth is consumed and the value function is simply given by $U_{T-x}\left(W_{T-x}\right)$.

The Bellman equations (8) and (9) cannot be solved analytically and hence a numerical technique is used. ${ }^{14}$ The basic algorithm operates as follows. First, at each point in time $t$ the $W_{t}$-state space is discretized into $I \in \mathbb{N}$ points $W_{t}^{i}$ with $i=1,2, \ldots, I$. The upper and lower bounds of this $W_{t}^{i}$-grid were chosen to be nonbinding in all periods. Since in the last period, i.e., at $t=T-x$, the value function $V_{T-x}\left(W_{T-x}\right)$ is given by $U_{T-x}\left(W_{T-x}\right)$, the numerical solution algorithm starts at the penultimate period, i.e., at $t=T-x-1$. The Bellman equations (8) and (9) are solved for each $W_{t}^{i}$ using the Mathematica ${ }^{\circledR}$ 5.1 implemented nonlinear optimizer NMaximize. ${ }^{15}$ For each $W_{t}^{i}$ this yields the optimal decisions $\alpha_{t}^{i}\left(W_{t}^{i}\right), C_{t}^{i}\left(W_{t}^{i}\right)$ and the function value of $V_{t}\left(W_{t}^{i}\right)$. Next, a continuous function is fitted to the points $V_{t}\left(W_{t}^{i}\right),{ }^{16}$ which delivers a continuous approximation of the value function $V_{t}\left(W_{t}\right)$. Finally, the problem is rolled back to the preceding period.

\section{Results}

\subsection{Base parameter configuration}

As explained in the previous section, the heir decides whether to participate in the family strategy by comparing his expected utility for both alternatives. The difference in utility can-as welfare gain (or loss) of the family strategy-be expressed in $€$-terms. For this purpose, we apply an equivalent wealth calculation, i.e., we calculate how much additional cash on hand $\Delta W_{0}$ the heir would need in the situation without the family strategy in order to make him indifferent between the two alternatives (Brown 2001). The results of this calculation are shown in Figure 1 for different amounts of $W_{0}$.

If the heir has cash on hand of $224 \mathrm{~T} €$, he will be indifferent between participating or not in the family strategy. Above (below) that amount, he would (would not) like to participate in the family strategy. Figure 1 illustrates that the whole decision problem is wealth driven, i.e., the welfare gain is higher the richer the heir is at $t=0$.

In principle, the family strategy is an investment with an expected financial gain of $84 \mathrm{~T} €$, which equals the life annuity's loading. ${ }^{17}$ But since this

14 The authors thank Roman Schulze (Humboldt-Universität zu Berlin (Germany)) for his invaluable ideas during the development of this solving technique.

15 The risky return and labor income distributions were also discretized to keep the optimization problem tractable.

16 The fitting algorithm is based on the Mathematica ${ }^{\circledR} 5.1$ implemented least-squares fitter Fit. The method used here guarantees that the relative risk aversion displayed by the optimal decisions $\alpha_{t}^{i}\left(W_{t}^{i}\right), C_{t}^{i}\left(W_{t}^{i}\right)$ is inherited to the continuous approximation of the value function $V_{t}\left(W_{t}\right)$.

17 The insurance load is calculated as follows: market premium $P$ (here, 300,000 €) minus fair insurance premium $P_{\text {fair }}$. The fair premium is calculated in the following way: $P_{\text {fair }}=$ $A \sum_{t=1}^{T-65}\left[R_{f}^{-t} \prod_{i=1}^{t} p_{i-1}^{r}\right]$. 


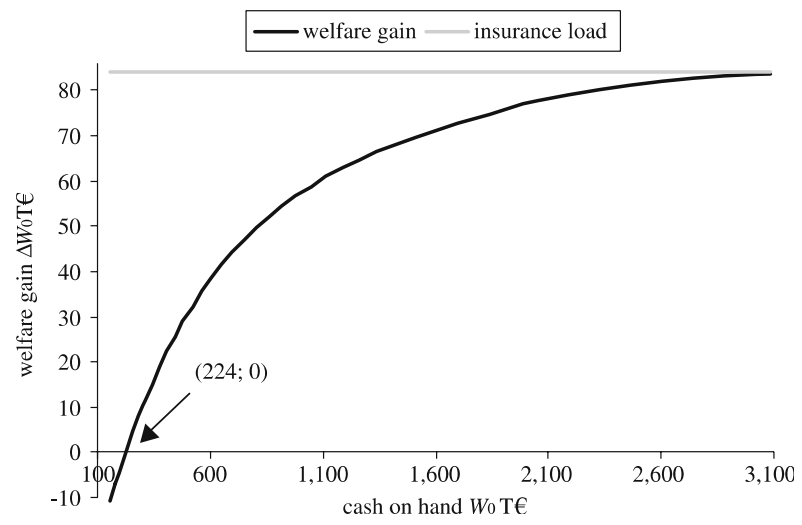

Fig. 1 The family strategy's welfare gain $\Delta W_{0}$ of the heir in Thousand $€$ (T€)

investment is also risky, the welfare gain measured by the value function is in general reduced by a risk premium. Since the proportion of both the risk for providing an annuity and the labor income risk decreases in the heir's overall portfolio the richer he is, the annuity is evaluated closer to its expected value. ${ }^{18}$ Furthermore, the wealthier the heir is, the less he is restricted (i.e., the less utility is lost) by the constraints (5)-(7).

In the following, we discuss some of the optimal saving/consumption and asset allocation decisions derived in the optimization process. In Figure 2, the optimal investment decisions at $t=0, \alpha_{0}$, are shown. Here, we look only at the case where the heir provides the annuity, which, based on Figure 1, is when the heir has cash on hand of at least $224 \mathrm{~T} €$. In contrast with Figure 1, the values are now given as a function in $\left(W_{0}+P\right)$, since this is the amount of money the heir has to work with after having received the premium $P(=300 \mathrm{~T} €)$ from the retiree. Optimal decisions for an heir who does not participate in the family strategy are given in the Appendix.

The straight line in Figure 2 shows the optimal asset allocation decision of an investor without background risk in his portfolio, i.e., without labor income and without annuity provision $\left(\alpha_{0} \approx 67 \%{ }^{19}\right)$. The gray curve shows the optimal asset allocation decision for that part of the heir's savings that are not required by the borrowing/collateral size and collateral investment constraints (5)-(6). This curve demonstrates that when providing the annuity and thus having to invest the collateral risk free, the heir would want to increase his risky position to more than $100 \%$ if he has a low amount of cash on hand $\left(W_{0}\right)$. In our model this is not possible because of the no-short-sale constraint (7). The more cash on hand the heir possesses, the more he can-outside the collateral-invest

\footnotetext{
18 This is a consequence of the constant relative risk aversion specification of the one-period utility function (2), which implies decreasing absolute risk aversion (Gollier 2001, pp. 17-37).

$19 \alpha_{0}$ is independent of the amount of cash on hand because of the constant relative risk aversion specification of the one-period utility function (2). See, e.g., Lenoir and Tuchschmid (2001) for an analysis of asset allocation decisions in such a situation.
} 


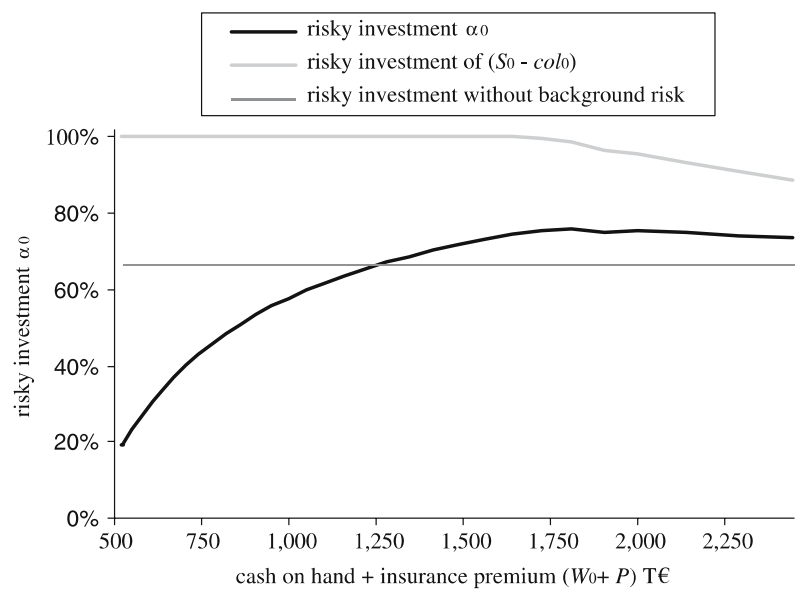

Fig. 2 Optimal decisions of the heir at $t=0$ when participating in the family strategy: asset allocation $\alpha_{0}$

riskily and this is why the optimal asset allocation curve including the collateral (black curve) begins with a positive slope. For larger amounts of cash on hand this curve converges to the optimal decision of an investor without background risk (straight line). Why does the black line not approach the straight line from below? The reason lies in the role that labor income plays in our model: labor income serves to some extent as a "nearly risk-free" asset for the heir (see, e.g., Spremann and Winhart 1998, Cocco et al. 2005). Together with the collateral, the heir is now "too much" invested in risk-free assets compared to the situation without annuity provision and labor income. The heir tries to offset this effect by investing more riskily than he would have done without labor income and the annuity provision. ${ }^{20}$ For very large amounts of cash on hand, labor income and the collateral become more and more unimportant in comparison to the heir's overall wealth position and therefore $\alpha_{0}$ converges to the straight line at about $67 \%$.

In the following Figure 3 we show optimal saving decisions $\left(S_{0}\right)$ at time $t=0$.

The different effects creating a U-shaped savings function (black curve) cannot be separated easily because of the complex interaction between the various risks and constraints in our model. First, savings are below the savings of an investor without background risk, i.e., without labor income and without annuity provision (in this case $\alpha_{0}$ is around $95 \%$ ), since the expectation of receiving labor income in future periods reduces the need for savings. This effect will be reduced with increasing $W_{0}$, since labor income becomes smaller in proportion to the value of the heir's whole portfolio, causing the increase in the savings

\footnotetext{
20 Another reason for the increase in the risky position here is the diversification effect of stochastic labor income, which is uncorrelated with the risky asset (see Gollier 2001, pp. 141-154). The effect of labor income which leads to an increase in the desired investment into the risky asset can also be seen in Appendix, where the optimal decisions of an heir not participating in the family strategy are shown.
} 


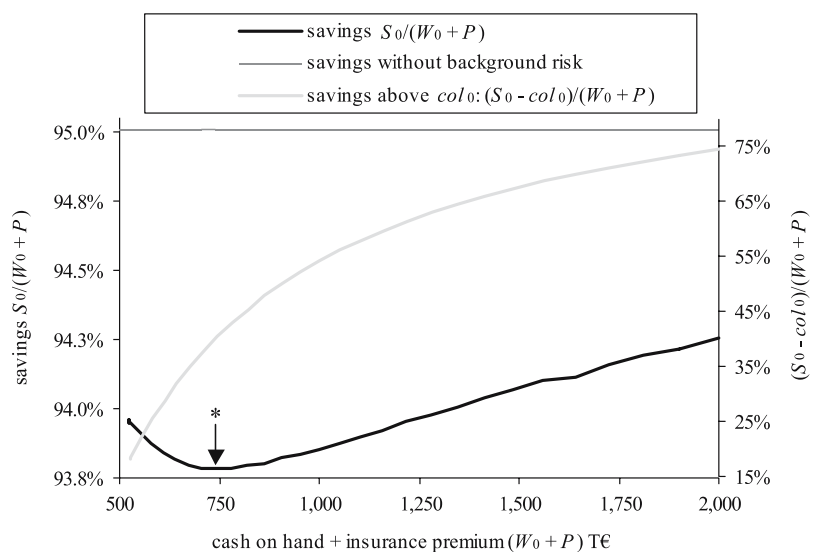

Fig. 3 Optimal decisions of the heir at $t=0$ when participating in the family strategy: savings $S_{0}$

function right of $*$ in Figure 3 (see Carroll and Kimball 1996). ${ }^{21}$ Second, a decreasing savings function for low levels of wealth is caused by the borrowing/collateral size constraint (5). Constraint (5) is not binding at $t=0-$ which can be seen from the existence of "voluntary" savings (gray curve "savings above col0" in Figure 3). But the "fear" of arriving at future periods in regions where constraint (5) does bind, drives up savings (Deaton 1991) the less cash on hand is available (left of $*$ in Figure 3 ). This motive is stronger the lower $\left(W_{0}+P\right)$ is, i.e., the savings function increases with decreasing $\left(W_{0}+P\right)$. Third, a similar effect, i.e., an effect that drives up savings for lower levels of wealth and vanishes for higher levels, is induced by the collateral investment constraint (6), forcing the heir to invest the amount $\mathrm{col}_{0}$ risk free. This reduces expected lifetime wealth because the return from this risk-free investment is lower than the expected return from the optimal portfolio without this constraint. Lower future wealth drives up savings because of the desire to smooth consumption over the life-cycle. ${ }^{22}$

\subsection{Parameter variations}

In this section we show how variation of some of the input parameters of the optimization problem given in Equations (3)-(7) influences the heir's optimal decisions and welfare gain $\left(\Delta W_{0}\right)$. We start with variations of the heir's preference parameters. Figure 4 compares the welfare gain through the family strategy of an heir with a subjective discount factor of $\delta=0.97$ (the original situation shown in Figure 1) with the welfare gain of an heir who has a subjective discount factor of $\delta=0.95$.

21 The effect of labor income to decrease savings can also be seen in Appendix where the optimal decisions of an heir not participating in the family strategy are shown.

22 Gollier (2001), p. 223 shows this effect in the case of a change of the risk-free rate of return. 


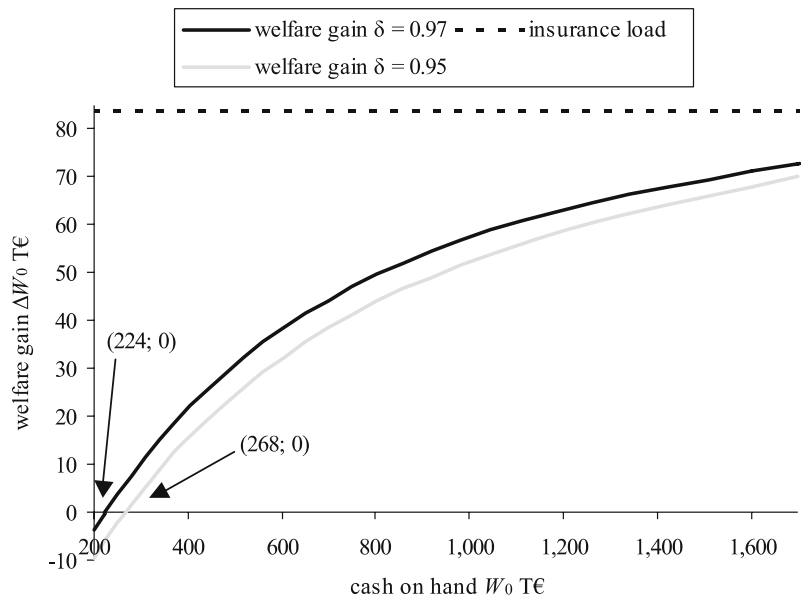

Fig. 4 The family strategy's welfare gain $\Delta W_{0}$ of the heir in T€; $\delta=0.97$ versus $\delta=0.95$

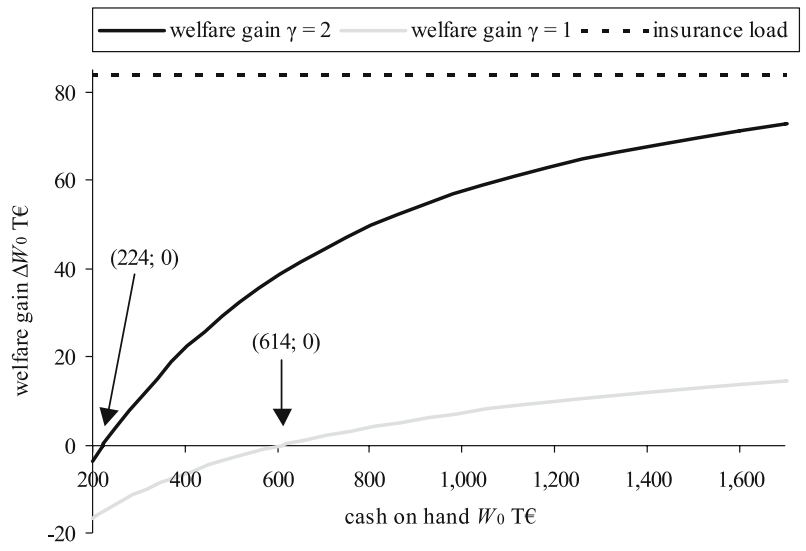

Fig. 5 The family strategy's welfare gain $\Delta W_{0}$ of the heir in T€; $\gamma=2$ versus $\gamma=1$

With $\delta=0.95$, the attractiveness of the family strategy is reduced, given a certain amount of $W_{0}$, because a lower $\delta$ reduces future utility of consumption and therefore reduces the desired level of savings. Hence, the borrowing/collateral size investment constraint (5) is more likely to be binding in future periods, which costs utility.

In Figure 5, we analyze the influence of different levels of constant relative risk aversion $\gamma$ of the one-period utility function (2) on the welfare gain $\left(\Delta W_{0}\right)$ of the heir.

On the one hand, decreasing relative risk aversion makes an individual more likely to accept risky gambles (in this case, taking part in the family strategy) and hence one would expect an increase in $\Delta W_{0}$. An increase of $\Delta W_{0}$ should also be supported by the fact that in the framework and calibration used in this model, 


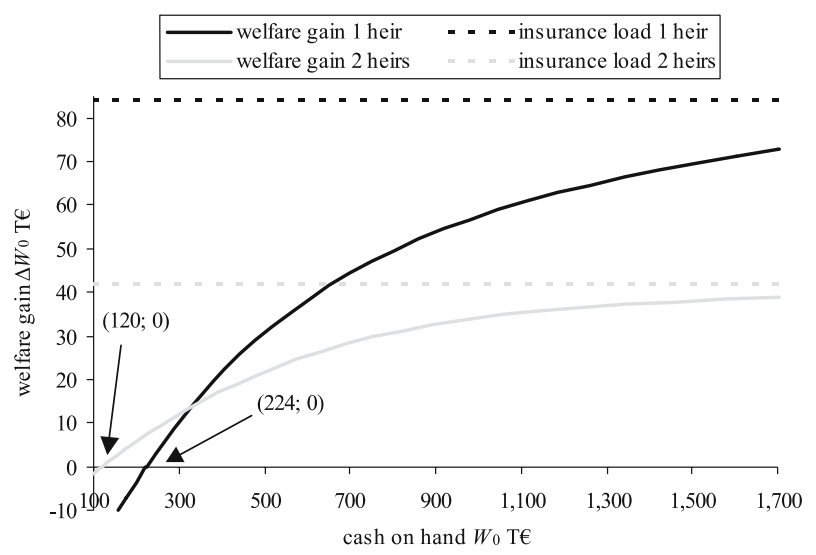

Fig. 6 The family strategy's welfare gain $\Delta W_{0}$ of the heir in T€; one versus two heirs

a lower $\gamma$ leads to higher savings, ${ }^{23}$ and hence the borrowing/collateral size constraint (5) is less likely to be binding in future periods. On the other hand, a lower $\gamma$ increases the propensity to invest riskily, which makes the risk-free investment of the collateral required by the collateral investment constraint (6) more painful for the heir (hence, $\Delta W_{0}$ decreases). Another effect that leads to a reduction of $\Delta W_{0}$ is that, in our setting, the wealth effect of future labor income is much smaller for an heir with $\gamma=1 .^{24}$ The last two effects outweigh the first two, so that in our calibration the overall $\Delta W_{0}$ decreases. ${ }^{25}$

A family strategy may often be based on the cooperation of several future heirs, typically several children. To get an insight into the effects resulting from such cooperation, we analyze in Figure 6 the situation where two identically equipped ${ }^{26}$ heirs participate in equal proportions in the family strategy. Hence, $P$ (annuity premium), $A$ (annuity payout), and $\mathrm{col}_{t}$ (collateral) are halved. All other input parameters are as described in the base parameter configuration (leading to the results shown in Figures 1,2).

Figure 6 illustrates that the minimum amount of $W_{0}$ necessary for agreeing to the family strategy is heavily reduced per heir because the risk resulting in providing the annuity is smaller in proportion to the overall portfolio of each

\footnotetext{
23 See also Gollier (2001), pp. 223-224, 235-248, and 269-283.

24 Usually, the wealth effect would be expected to be larger for a $\gamma=1$ investor since he is less risk averse. In our calibration, the no-short-sale constraint (7) leads to a comparatively smaller wealth effect of labor income: the gain from diversification by adding stochastic labor income-leading to an increase of the risky investment $\alpha_{t}-$ is 0 for a $\gamma=1$ investor because such an investor already chooses the riskiest asset allocation allowed (regardless of the cash on hand $W_{0}$ ).

25 We also checked our calculations with a relative risk aversion parameter of $\gamma=3$. These calculations support our explanations for the " $\gamma$-effect". With $\gamma=3$, especially the collateral investment constraint (6) is less likely to be binding, since a more risk averse heir wants to invest less money into the risky asset. Consequently the minimum amount of cash on hand to convince the heir to participate in the family strategy decreases to $148 \mathrm{~T} €$, whereas the welfare gain $\Delta W_{0}$ increases.

26 This means that both heirs have the same cash on hand, labor income, marginal tax rate, preferences, age, sex, and mortality.
} 


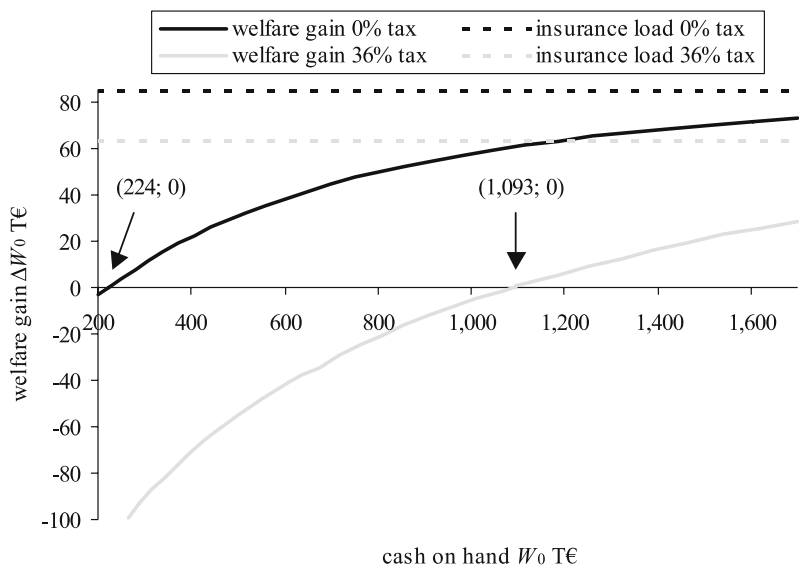

Fig. 7 The family strategy's welfare gain $\Delta W_{0}$ of the heir in $\mathrm{T} € ; 0 \%$ versus $36 \%$ marginal tax rate

heir. One can also see that the minimum amount of $W_{0}$ required for participation does not shrink by $50 \%$. As a result of the constant relative risk aversion feature of the one-period utility function (2), this would be the case only if the labor income were halved as well.

In the next variation, illustrated in Figure 7, the tax situation is changed. Now the retiree and the heir each have a marginal tax rate of $36 \%$. In general, according to German income tax law, interest and dividends are subject to taxation but capital gains are not. Annuity payouts are treated only partially $(18 \%)$ as taxable income. This changes the annual annuity payment $A$ to 19,185 $€, \mathrm{E}\left(R_{t}\right)$ to $1.1360, \operatorname{Std}\left(R_{t}\right)$ to 0.3119 , and $R_{f}$ to $1.0302 .{ }^{27}$ To avoid pure income effects, we used the same labor income stream after taxation as in previous scenarios. All other input parameters are as described in the base parameter configuration (leading to the results shown in Figures 1,2).

In the case of a $36 \%$ marginal tax rate, the welfare gain through the family strategy $\Delta W_{0}$ is enormously reduced. There are four main reasons for this. First, annuities enjoy a comparative advantage over other investments since only a small proportion of annuity payouts is taxed. This effect reduces the insurance load from $84 \mathrm{~T} €$ to $63 \mathrm{~T} €{ }^{28}$ which makes the family strategy generally less attractive to the heir. Second, the desired proportion of risky investment $\alpha_{t}$ is generally increased because capital gains are not taxed under German tax law. Therefore, the utility reducing collateral investment constraint (6) and the noshort-sale constraint (7) are more likely to be binding. Third, since the necessary

\footnotetext{
27 Details and references explaining tax adjustments in Germany can be found in Schmeiser and Post (2005). Note that due to an amendment of the income tax law, the proportion taxable of the annuity payout decreased to $18 \%$ (compared to $27 \%$ used in Schmeiser and Post 2005).

28 This result is obtained using the formula shown in footnote 16 for the calculation of the fair premium, setting $A$ to $19,185 €$ and $R_{f}$ to 1.0302 while holding the survival probabilities constant. The insurance load can be calculated by subtracting the fair premium $(237 \mathrm{~T} €)$ from the market premium $(300 \mathrm{~T} €)$.
} 
amount of collateral $\mathrm{col}_{t}$ is calculated by discounting future annuity payments with $R_{f}$, a reduction of $R_{f}$, e.g., increases $\operatorname{col}_{0}$ by $119 \mathrm{~T} €$ (from 396 to $515 \mathrm{~T} €$ ), making the borrowing/collateral size constraint (5) more likely to be binding. Fourth, as already demonstrated, the decision problem is highly wealth driven. Given a certain amount of cash on hand $W_{0}$, an heir with a $36 \%$ marginal tax rate simply has less wealth over his lifetime than an heir with a $0 \%$ marginal tax rate. This causes a reduction of $\Delta W_{0}$ as well.

In our last scenario, we again use the situation given in Figure 7 (36\% marginal tax rate), but assume that the retiree has a higher than average life expectancy. This case is chosen to incorporate empirical evidence that wealthier people generally have an above average life expectancy (e.g., Brown 2003). This parameter combination leads to a situation where the family strategy is very rarely attractive (the "worst-case" scenario for the strategy). In the following calculation, we use the German life-table "DAV 1994 R" (see Schmithals and Schütz 1995), which reflects the higher life expectancy of typical annuity buyers. $^{29}$ The mortality assumptions about the heir are held constant (average population mortality) in order to make the results easier to compare with the outcome given in Figure 7 where both heir and retiree have an average life expectancy.

The negative influence of using annuitant mortality on $\Delta W_{0}$ is not surprising, taking into account that the insurance load decreases further from $63 \mathrm{~T} €$ to $27 \mathrm{~T} €$. This clearly makes the family strategy less attractive.

\section{Discussion and conclusion}

We derived the optimal decisions and calculated welfare gains from a family oriented self-annuitization strategy in a realistically calibrated intertemporal consumption/saving framework. Our results show that participating in a family strategy can be optimal if the heir has a certain amount of wealth (see in particular Figures 1, 4, 6). In such a situation, families can reach a Pareto-improved position by choosing the family strategy as their retirement arrangement. They also may alter the terms of such an agreement in order to divide welfare gains between both generations (retiree and heir). In such case, the welfare gain curve (e.g., in Figure 1) shifts downward by the amount of money transferred from the heir to the retiree under a "welfare gain sharing agreement." Consequently, the minimum amount of cash on hand necessary for participation in the family strategy shifts to the right, i.e., the heir needs to be wealthier to make the family strategy an acceptable choice.

We have seen that the decision problem is wealth driven, i.e., the more cash on hand the heir has, the more likely it is that he would like to participate in this strategy, which is a possible drawback to our concept of a family strategy.

29 By using this annuitant life-table instead of the table of the Federal Statistical Office of Germany, the life expectancy of the retiree is increased by 3.4 years. Differences in life expectancy between the general population and annuitants can be explained by adverse selection effects. The life-table DAV $1994 \mathrm{R}$ is also a cohort table, i.e., a table that differentiates mortality by the year of birth. 


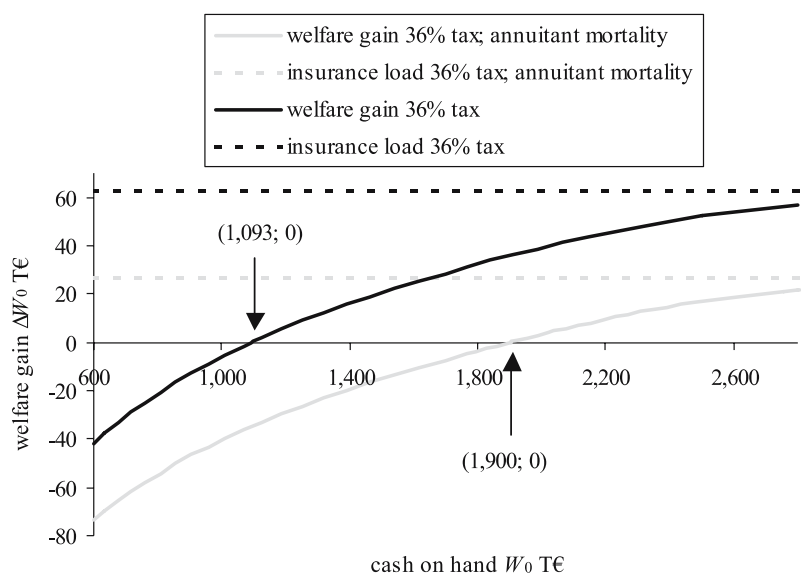

Fig. 8 The family strategy's welfare gain $\Delta W_{0}$ of the heir in $\mathrm{T} € ; 36 \%$ marginal tax rate, average versus annuitant mortality

The heir's above average wealth is positively correlated to the above average wealth of the retiree (e.g., Zimmermann 1992; Dustmann 2004). This again is correlated to above average life expectancy of the retiree (Brown 2003). Furthermore, wealthier people are generally in higher income tax brackets. Both effects, i.e., high life expectancy and high tax rates, make a family strategy rather unattractive (see Figures 7, 8).

Another assumption influencing the attractiveness of the family strategy substantially is the size of the collateral required for participation. In our model, the collateral equals the discounted sum of annuity payments if the retiree lived to be 121 years old. Schmeiser and Post (2005) chose to make the collateral equal to a (single) annuity premium large enough to provide the required payment stream. This premium is considerably smaller than $\mathrm{col}_{t}$ which would c.p. increase the attractiveness of the family strategy. However, this leads to an additional risk concerning the decision problem since future annuity prices are not certain from the perspective of $t=0$. This greatly complicates the solving algorithm. Additionally, the Schmeiser and Post (2005) approach requires a market where annuities are sold up to an annuitant's entry age of 120.

From a decision theoretic point of view, it would be interesting to know how a family strategy would be negotiated inside the family if there is more than one heir. As shown in Figure 6, the desired proportion of annuity provision by each heir depends on his individual characteristics, e.g., cash on hand. This may lead to controversies over participation shares. However, it should be possible to find some scheme of participation that all family members could agree to and benefit from since a starting prerequisite for a family strategy is a certain level of mutual trust and honesty (as in Kotlikoff and Spivak 1981). Otherwise, the whole scheme would be subject to moral hazard concerns. The retiree might fear that the heirs would try to renegotiate the deal if he lives longer than 
expected or the stock market performs poorly or the heirs become unemployed and thus suffer a drop in income (Schmeiser and Post 2005).

In summary, in our realistically calibrated model, the family strategy is accepted for many parameter combinations. It is especially suitable for families with low marginal tax rates, wealthy heirs, or where the retiree has an average population life expectancy. ${ }^{30}$ For such families, a family strategy should be seriously considered as retirement arrangement. Under realistic conditions our results support two explanations of the annuity puzzle, namely intra-family risk sharing and high cost of market-annuitization.

Acknowledgements The authors wish to thank the anonymous referees for helpful comments.

\section{Appendix: Optimal decisions for an heir not participating in the family strategy}

The optimal decisions for an heir who does not participate in the family strategy are shown in Figures 9 and 10 for the base parameter configuration.

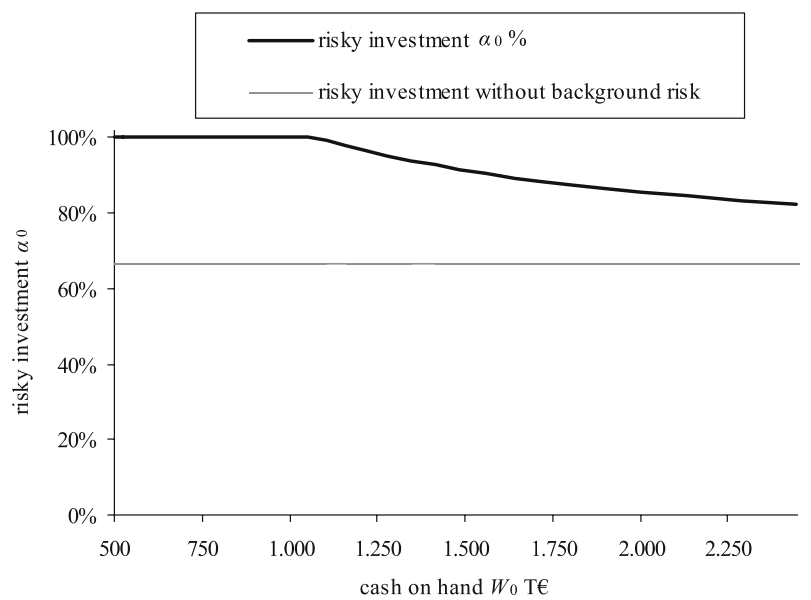

Fig. 9 Optimal decisions for the heir at $t=0$ when not participating in the family strategy: asset allocation $\alpha_{0}$

Figures 9 and 10 reveal the influence of stochastic labor income on the optimal decisions for an heir not participating in the family strategy. To some extent, stochastic labor income serves as a risk-free asset, and the heir tries to offset this effect (shown in Figure 9) by investing more riskily than he or she would have done without labor income (= straight line, see, e.g., Spremann and Winhart 1998, Cocco et al. 2005). Furthermore, future labor income works as a

\footnotetext{
30 In case of compulsory unisex annuity pricing a family strategy might still be attractive for male retirees, even if the retiree has a higher than average population life expectancy (Schmeiser and Post 2005). The European Commission recently proposed such pricing for annuities. For government subsidized annuities unisex pricing is already required in Germany.
} 


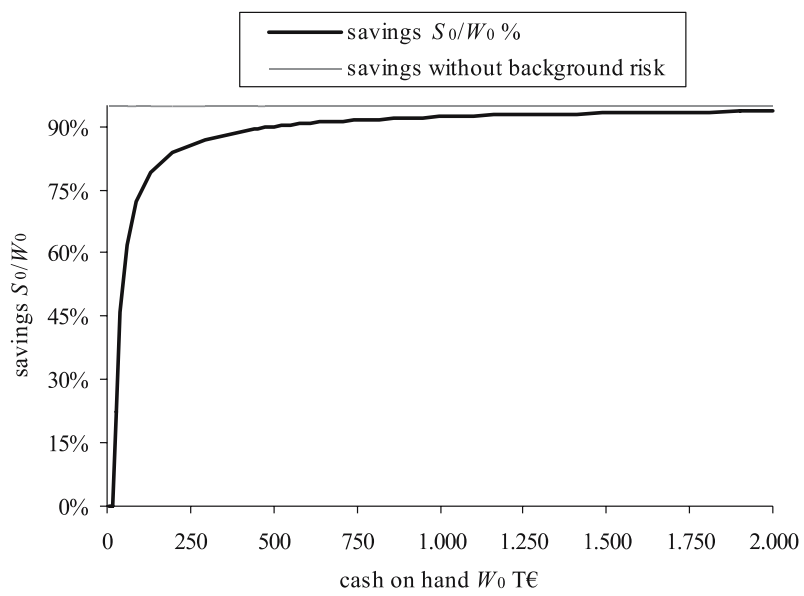

Fig. 10 Optimal decisions for the heir at $t=0$ when not participating in the family strategy: savings $S_{0}$

substitute for savings, and thus the savings (shown in Figure 10) of an heir with this sort of income decrease (see Carroll and Kimball 1996) compared to those of an individual without labor income (= straight line). Both effects will be reduced with increasing $W_{0}$, since labor income becomes smaller in proportion to the value of the heir's whole portfolio. Thus the optimal decisions approach the straight lines.

\section{References}

Albrecht, P., Maurer, R.: Self-annuitization, consumption shortfall in retirement and asset allocation: the annuity benchmark. J. Pension Econ. Finance, 1, 269-288 (2002)

Behr, A., Bellgardt, E., Rendtel, U.: The estimation of male earnings under panel attrition. A cross country comparison based on the European Community Household Panel. Chintex Working Paper No. 7, World Wide Web: http://www.destatis.de/chintex/download/paper11.pdf (accessed on May 23, 2006) 2003

Blake, D., Cairns, A., Dowd, K.: Pensionmetrics 2: stochastic pension plan design during the distribution phase. Insur. Math. Econ. 33, 29-47 (2003)

Brown, J.R.: Private pensions, mortality risk and the decision to annuitize. J. Public Econ. 82, 29-62 (2001)

Brown, J.R.: Redistribution and insurance: mandatory annuitization with mortality heterogeneity. J. Risk Insur., 70, 17-41 (2003)

Brown, J.R., Poterba, J.M.: Joint life annuities and annuity demand by married couples. J. Risk Insur., 67, 527-554 (2000)

Carroll, C.D., Kimball, M.S.: On the concavity of the consumption function. Econometrica, 64, 981-992 (1996)

Cocco, J., Gomes, F.J., Maenhout, P.: Consumption and portfolio choice over the life-cycle. Rev. Financ. Stud., 18, 491-533 (2005)

Dammon, R.M., Spatt, C.S., Zhang, H.H.: Optimal asset location and allocation with taxable and tax-deferred investing. J. Finance, 59, 999-1037 (2004)

Davidoff, T., Brown, J.R., Diamond, P.A.: Annuities and individual welfare. Am. Econ. Rev., 95, 1573-1590 (2005)

Deaton, A., 1991, Saving and Liquidity Constraints, Econometrica, 59, 1221-1248. 
Dustmann, C.: Parental background, secondary school track choice, and wages. Oxf. Econ. Pap., 56, 209-230 (2004)

Federal Statistical Office Germany: Datenreport 2002, Zahlen und Fakten über die Bundesrepublik Deutschland (Bonn: Bundeszentrale für politische Bildung) (2002)

Federal Statistical Office Germany: Bevölkerung Deutschlands bis 2050 - Ergebnisse der 10. koordinierten Bevölkerungsvorausberechnung. World Wide Web: http://www.destatis.de/presse/deutsch/pk/2003/Bevoelkerung_2050.pdf (accessed on May 23, 2006) (2003)

Federal Statistical Office Germany: Statistical Yearbook 2003 for the Federal Republic of Germany. (Wiesbaden: Federal Statistical Office Germany) (2004)

Fitzenberger, B., Wunderlich, G.: Gender wage differences in West Germany: a cohort analysis. Ger. Econ. Rev. 3, 379-414 (2002)

Gollier, C.: The Economics of Risk and Time. The MIT Press, Cambridge, MA (2001)

Gomes, F., Michaelides, A.: Portfolio choice with internal habit formation: a life-cycle model with uninsurable labor income risk. Rev. Econ. Dyn., 6, 729-766

Gomes, F., Michaelides, A.: Optimal life-cycle asset allocation: understanding the empirical evidence. J. Finance, 60, 869-904 (2005)

Hull, J.C.: Options, Futures, and Other Derivatives. Prentice Hall, Upper Saddle River (2005)

Kotlikoff, L.J., Spivak, A.: The family as an incomplete annuities market. J. Polit. Econ., 89, 372-391 (1981)

Laibson, D.I., Repetto, A., Tobacman, J.: Self-control and saving for retirement. Brookings Pap. Econ. Act., 1998, 91-196 (1998)

Lauer, C.: Education and Unemployment: A French-German Comparison. ZEW Discussion Paper No. 03-34, World Wide Web: http:/WWW.ssrn.com/abstract=439742 (accessed on May 23, 2006), (2003)

Lenoir, G., Tuchschmid, N.S.: Investment time horizon and asset allocation models. Financ. Mark. Portf. Manage., 15, 76-93 (2001)

Milevsky, M.A.: The implied longevity yield: a note on developing an index for life annuities. J. Risk Insur., 72, 301-320 (2005)

Milevsky, M.A., Ho, K., Robinson, C.: Asset allocation via the conditional first exit time or how to avoid outliving your money. Rev. Quant. Finance Account., 9, 53-70 (1997)

Milevsky, M.A., Robinson, C.: Self-annuitization and ruin in retirement. North Am. Actuar. J., 4, 112-129 (2000)

Milevsky, M.A., Young, V.R.: Annuitization and asset allocation. In: Individual Finance and Insurance Decisions Centre, working paper, University of Toronto, Toronto (2003)

Milevsky, M.A., Young, V.R.: The timing of annuitization: investment dominance and mortality risk. In: Individual finance and Insurance Decisions Centre, working paper, University of Toronto, Toronto (2005)

Mitchell, O.S., Poterba, J.M., Warshawsky, M.J., Brown, J.R.: New evidence on the money's worth of individual annuities. Am. Econ. Rev., 89, 1299-1318 (1999)

Rodepeter, R., Winter, J.: Rules of thumb in life-cycle saving decisions, working paper, LudwigMaximilians-Universität München, München (2005)

Schmeiser, H., Post, T.: Life annuity insurance versus self-annuitization: an analysis from the perspective of the family. Risk Manage. Insur. Rev., 8, 239-255

Schmithals, B., Schütz, E.U.: Herleitung der DAV-Sterbetafel 1994 R für Rentenversicherungen. Blätter Deutschen Gesellschaft Versicherungsmathematik, 22, 29-69 (1995)

Spremann, K., Winhart, S.: Anlageberatung und Lebenszyklus. Financ. Mark. Portf. Manage., 12, 150-169 (1998)

Vidal, C., Lejárraga, A.: Demand for life annuities from married couples with a bequest motive. J. Pension Econ. Finance, 5 (in press) (2006)

von Gaudecker, H., Weber, C.: Surprises in a growing market niche: an evaluation of the german private life annuities market. Geneva Pap. Risk Insur., Issues Pract., 29, 394-416 (2004)

Wilke, R.A.: New estimates of the duration and risk of unemployment for West-Germany. J. Appl. Soc. Sci. Stud. (Schmollers Jahrbuch) 125, 207-237 (2005)

Yaari, M.E.: Uncertain lifetime, life insurance, and the theory of the consumer. Rev. Econ. Stud., 32, 137-150 (1965)

Young, V.R.: Optimal investment strategy to minimize the probability of lifetime ruin. North Am. Actuar. J., 8, 106-126

Zimmerman, D.J.: Regression toward mediocrity in economic stature. Am. Econ. Rev., 82, 409-429 


\section{Author's Biographies}

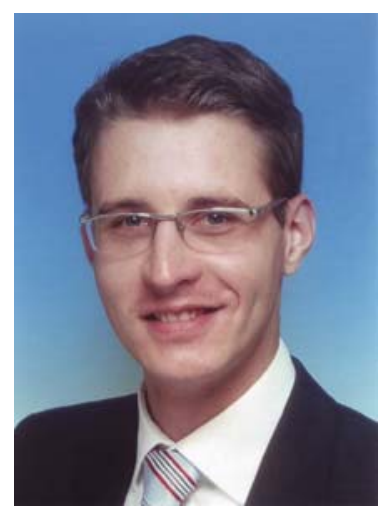

Thomas Post studied business administration at the Humboldt-Universität zu Berlin, Germany. From 2002 to 2003 he worked as an audit assistant for the insurance branch of KPMG. Since then he is research assistant at the Dr. Wolfgang Schieren Chair for Insurance and Risk Management at the Humboldt-Universität zu Berlin. His main research interests include individual financial planning, optimal annuitization, asset-liability-management for insurance companies, and demographic risk.

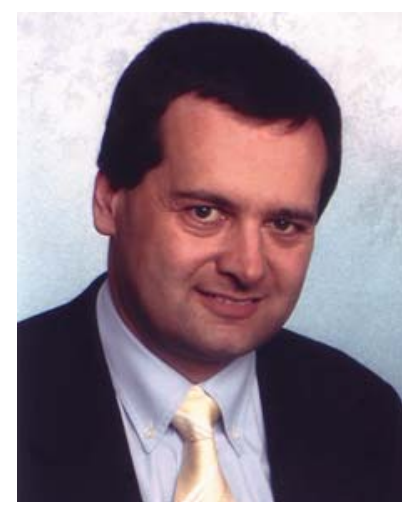

Helmut Gründl studied business administration at the University of Passau, Germany. From 1990 to 1999 he worked as research assistant at the Chair for Insurance and Risk Theory at the University of Passau, where he received his doctoral degree and the postdoctoral lecture qualification (Habilitation) in 1998. In 1999, he was appointed Professor for Insurance and Risk Management at the Humboldt-Universität zu Berlin. His main research interests include value-based management of insurance companies, financial planning, solvency regulation in the insurance industry, and demographic risk.

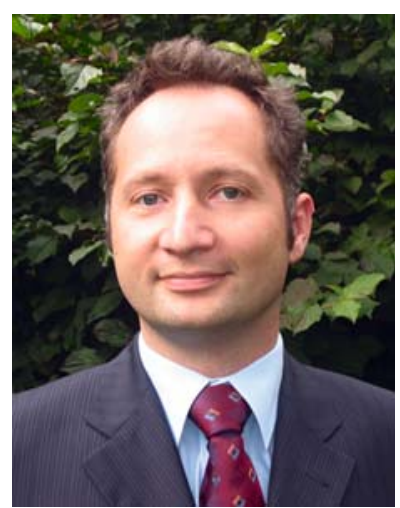

Hato Schmeiser studied business administration at the University of Manheim, Germany. After his doctoral degree and the postdoctoral lecture qualification (Habilitation) in 2003 (Humboldt-Universität zu Berlin), he was appointed Professor for Insurance and Risk Management at the University of Münster. Since 2005, he is Chair for Risk Management and Insurance at the University of St.Gallen. His main research interests include individual financial planning, dynamic financial analysis, option pricing, and regulation of financial firms. 